\title{
Slavophile Tendencies in Post-Soviet Social Thought
}

\author{
Yulia Zalozhnych ${ }^{1, *}$
}

\author{
${ }^{1}$ Department of Philosophy, Moscow State Regional University, Moscow, Russia \\ *Corresponding author. Email: semga@bk.ru
}

\begin{abstract}
The article analyzes the development of the basic socio-philosophical ideas of the Slavophiles in postSoviet social thought. The main goal is an identify the existence of the Slavophile trend and its relevance in the realities of modern Russian society. The author highlighted three thematic blocks of social and philosophical views of the Slavophiles: issues about statehood and power, ideas about the Russian nationality and community, and a body of thought devoted to the Orthodox faith and the church. Relating the ideas of the Slavophiles with the Russian public discussion of the last decades, the author revealed those of them that are the most relevant today. Also, Slavophil ideas were identified that underwent transformation in accordance with the realities of the time. In addition, the article lists representatives of the Russian scientific community, politicians, public figures, economists, journalists, and the cultural and creative elite who, calling themselves supporters of Slavophile-soil ideas in modern Russia, transmit and defend views that are close to them.
\end{abstract}

Keywords: Slavophiles, society, relevance, state, nationality, Orthodoxy, followers

\section{INTRODUCTION}

After the collapse of the Soviet Union, our country entered into a new historical stage. Laying the vectors of further civilizational development, Russian society had to look for ways to overcome the crisis that had arisen in the economy, in political and public administration and in relations in the international arena.

With this impact on all the main spheres of human life, there came significant changes in mentality and morality in Russian society. At present, we are witness to the destruction of the basic values of the family, the levelling of national traditions, the surge of hedonism as a way of life, the growth of the consumerism cult, profit and an idle lifestyle.

The culture's issues, the loss of moral and spiritual guidelines, a decrease in the level of patriotism - all this has become a significant focal point in the discussions of recent decades. The comprehension of the tasks of education and upbringing, the search for the identity and unity of society also did not diminish their urgency and acuteness.

When looking for answers to the questions posed, it is fundamentally important not to abandon the already accumulated intellectual heritage of past eras. A special place in the Russian social thought is occupied by the philosophical trend of the Slavophiles, original and extraordinary thinkers of the 19th century. The impulse given by them has survived to this day, giving rise to new discussions and causing a wide public resonance.
The topic of identity received serious reflection for the first time in Russian philosophy, starting from Pyotr Chaadayev's "The Philosophical Letters" and the further debate about them between the Slavophiles and Westerners.

At the beginning of the XIX century the Slavophiles were among those few thinkers who raised the issue of the need for national self-reflection. The Slavophiles comprehended Russian culture and society, relying on the preservation and cultivation of the Orthodoxy values, and advocated for refusing to passively copy the spiritual foundations of other countries [1].

In the present the Slavophile heritage can become a philosophical base and help determine the future direction of Russia's development and overcome the current crisis through reliance on the national foundations of the society's organization "to then develop these principles, while taking from the West all its positive achievements" [2].

The thinkers tried to show that through awareness of their identity, Russia can reveal its internal potential and uncover opportunities. This requirement of preserving one's own specificity during the modernization of various areas of human life allows us to characterize this trend as both a theoretical basis and an attempt to search for another way for Russian society to develop in a framework of conservatism.

If in the 1990s the most popular direction in Russian public discourse was Westernism, the main ideas of which were adopted for practical implementation in an ultra-extreme version [3], then in recent decades the 
emphasis of social self-reflection has shifted. Classical Slavophilism and its various modifications (especially Pochvennichestvo) are beginning to take on special significance. As such, ideas that are similar in content to those offered by the Slavophiles can be found today in people of various professions and fields of activity (scientists, political and public figures, economists, writers, journalists, directors, artists, musicians, and others) who include them in their intellectual creativity and use them in programs and strategies in evaluating current events.

As the achievements of the Slavophiles actively appeal to the discourse and interests of the Russian public, this allows us to talk about the relevance of their ideas in the realities of the present. From here, hypothetically we can state the formation of a certain Neo-Slavophile line in the Russian public thought in recent decades.

The philosophical heritage of the Slavophiles is diverse. The thinkers left behind a significant ideas: socio-political views, ideas on the philosophy of history, epistemology, cultural studies, theology, a sufficiently developed philosophical and anthropological concept, groundwork on pedagogy, etc.

\section{THE IDEAS OF SLAVOPHILES ABOUT STATEHOOD IN MODERN PUBLIC RUSSIAN THOUGHT}

We would like to analyse only the sociophilosophical views of thinkers.

The socio-philosophical heritage of the Slavophiles, presented today in a public discussion, can be divided into three thematic blocks: statehood and the issues of power, ideas about the Russian nationality and community and a body of thought devoted to the Orthodox faith and the church.

It should be noted that the Slavophile thinkers left behind a fairly developed body of ideas about power, politics and statehood in Russia. Among them, the following can be noted:

- State power is a special kind of contractual relationship. Being, according to the ideas of the Slavophiles, only an empty mechanical form, it requires filling with valuable content and morality [4].

- The state is a necessary and obligatory component of a public life, allowing to consolidate the forces and aspirations of the people, as well as performing security and organizational functions [5].

- The state, standing in the value hierarchy of the Slavophiles below the nationality and
Orthodoxy, should develop within the framework of the Orthodox culture.

- The people, having their own historical mission, voluntarily withdraws from power relations and politics, passing it on to one person. Hence, the best form of power for Russia is the monarchy [6].

- A ruler, clothed with power, must have high morality and spirituality, perceive power as a burden that requires internal strength and perseverance.

- The historical form of Russian statehood (especially after the reforms of Peter I) is significantly different from the exemplary and has many vices that require eradication (bureaucracy, bribery, nepotism, etc.).

- Along with strong power, the Slavophiles put forward the idea of resuming the convocation of Zemsky Sobors as an openly proclaimed public opinion and the development of forms of selforganization of the people traditional for Russian culture (Zemstvo, veche assemblies), which form a union of people and power. At the same time, the Slavophiles opposed the adoption of the constitution, considering it unnecessary and even dangerous at this stage of the country's historical development [7].

Analysing the Slavophilic ideas that are widespread today in Russian society, it can be noted that many of the above voiced views are present in public discourse.

The idea of a strong, centralized power, approaching in its characteristics to autocracy is the most popular among them. Representatives of the Russian Monarchist Social Movement have the greatest similarity in views with the Slavophiles on this issue, the program principles of which speak of the Orthodox monarchy, based on morality and religious principles, the purpose of which is to serve the Russian people [8]. Director N. Mikhalkov, scientists M.B. Smolin, L.P. Reshetnikov and V. Karpets, historian O. Platonov, writer M. Weller, Orthodox publicist V. Filimonov, artist I. Glazunov, scientist F.Ya. Shipunov call themselves supporters of the monarchy in Russia [9].

For strong centralized power with an expansion of management powers is supported by scientists $\mathrm{N}$. Narochnitskaya, V. Katasonov and A. Schipkov, TV presenter Z. Prilepin, actor I. Okhlobystin, journalist M. Leontyev, politician E. Fedorov, writer A. Prokhanov and others [10]. Most of them also uphold the need for a strong moral component in characterizing the ruler and perceive the power not as a means to realize personal interests, but as a heavy burden that only a person of great strength and high morality is able to bear. 
In addition, today they are quite in demand: the Slavophile idea of the need to develop forms of local self-government, the requirement to build their own statehood on the basis of religious traditions, history and culture of the Russian people, as opposed to the uncontrolled borrowing of other people's forms; criticism of the flaws and shortcomings of the real form of government and the search for practical ways to address them. Among the supporters of these ideas, we can name scientists and public figures: $\mathrm{N}$. Narochnitskaya, A. Schipkov, R. Mikhailov, D. Badovsky, S. Baturin, publicist G. Lodochnik, journalist M. Leontyev and others [11].

It is necessary to clarify that today not all the voiced principles of the Slavophiles exist in their original and unchanged form, a number of them are being transformed and modified in accordance with the realities of the time. So most modern proponents of Slavophilism, as opposed to thinkers of the XIX century, hold the view that the constitution is necessary as the basic law and regulator of the life of the people, which is an important difference between them.

\section{SLAVOPHIL IDEAS ABOUT NATIONALITY IN THE RUSSIAN PUBLIC DISCUSSION}

The concept of nationality is one of the keys in the Slavophile philosophy and combines a number of issues that are significant for thinkers.

- Nationality in the understanding of philosophers is the internal spiritual content of the Russian people, a number of certain characteristics that distinguish the Russian nation from others and allow it to create an original culture, form of social structure, etc.[12].

- The nationality was formed under the influence of natural and geographical features and historical events, but its main foundation is the Orthodox faith. Nationality is reflected in the artistic creation, faith, traditions and everyday life of people.

- The Slavophiles distinguish a number of typological features of Russians, the main of which are: the desire for collectivism, conscientiousness, readiness to sacrifice, patience, the priority of truth over laws [13].

- The Russian people, and not the person, according to the Slavophiles, is the main figure in history.

- Pre-Petrine Russia was a model of the unity of the people and the state, which must be taken as a basis.

- The community, built on the principles of internal freedom and justice, is a primordial
Russian beginning. Its development can become the basis for the progress of the whole society, including in the field of local self-government. The community allows individuals to avoid the temptations of individualism and resist external influences. Community life contributes to the formation and strengthening of the moral principles of society [14].

- The peasant, as a direct member of the community, is the basic unit of Russian society. It is this part of the Russian nation after the Petrine schism that preserves and translates the values and traditions of Russian culture and will become the basis for Russia's return to the original path of development.

The modern Russian public discussion, to one degree or another, includes all the above voiced ideas. Statistical studies of recent years reflect the presence and growth of the number of Slavophiles supporters on the issue of national identity among the wide mass population of Russia [15].

The most broadcast ideas in public rhetoric today are the ideas of philosophers about the presence of a complex of special features among the Russian people, formed under the influence of objective conditions of existence, which in turn determine the characteristics and forms of their lives. Supporters of this idea include scientists: A. Panarin, A. Korolkov, N. Narochnitskaya, writer Yu. Polyakov, director S. Govorukhin and others [16].

Much attention is paid to the historical tasks of the Russian nation and the need to choose its distinctive, independent path of development. Similar thoughts can be seen in the works of A. Solzhenitsyn, V. Putin [17], Z. Prilepin, M. Kantor, S. Yamshchikov, V. Minin.

The problem of a split in Russian society persists and even escalates. A. Korolkov, V. Fateev, V. Soloviev, and others talk about it.

The ideas about the value of the community lifestyle and its relevance in the modern world have less interest. The philosopher A. Schipkov writes in sufficient detail about the community, understanding and comprehending it precisely in the spirit of the early Slavophiles [18]. You can also name the scientist V. Katasonov, public figure L. Ivashov, director V. Khotinenko. In addition, today (for example, in the Kaluga and Belgorod regions), practical attempts are being made to organize an agricultural community and to adapt this form of life to modern historical conditions.

Thus, it seems reasonable to us to state the existence and active dynamics of the Slavophile ideological heritage regarding the problem of nationality in postSoviet social thought. 


\section{THE SLAVOPHILE IDEA OF FAITH'S DEVELOPMENT IN THE POST-SOVIET PERIOD}

In the focus of the intellectual heritage of the Slavophiles are ideas about religion, faith and the church, which combine the rest of the Slavophile philosophy into a single whole.

- According to philosophers, faith is the spiritual core and the main factor determining all spheres of life, history and the cultural and national identity of peoples [19].

- The people and religious beliefs mutually determine each other: the people profess faith according to the capabilities of the spirit, and faith determines the social and state structure, way of life, etc.

- The difference in the forms of religious worldview gives rise to differences between Russia and the West. Russian Orthodoxy is a combination of unity, freedom and love, opposes European Catholicism and Protestantism with their one-sided development, the influence of antiquity, violence as a factor in European history and a number of other reasons that led to the lack of harmony between unity and freedom of believers.

- The main characteristic of Western Christianity, according to the Slavophiles, is the strengthening of rational principles and the complete rule of rationalism. This caused Slavophile criticism of Western culture and the denial of the possibility of adopting all its principles for the development of Russia.

- Orthodoxy as the purest form of Christianity is organically close to the spiritual structure of the Russian people and therefore has become the basis for the development of Russia, the key to spiritual growth.

- The Orthodox faith created the Russian people as a nation with a common historical destiny and determined such qualities of Russian people as: the desire for truth, humility, a heightened sense of justice, conscience, etc.

- The Slavophiles derive from Orthodoxy the great historical task of Russia as a mission to overcome the rationalism of European Enlightenment and to rebuild the world on the principles of love, truth and good. It is the Russian people that will become the spiritual saviour of mankind and a model of high morality.

- The most important concept of Slavophile philosophy is collegiality, understood as a multitude, united by the power of love into a free unity. The church is an example of a conciliar community of people. The basis of prePetrine's Russia organisation was precisely collegiality [20].

- The peasant community, with its collective responsibility, common land tenure, sense of justice and traditionalism, is a clear embodiment of the principle of collegiality in public life.

- Noting the paramount importance of the Orthodox Church in the Russian history, the Slavophiles criticized the real functional institution of the church for mistakes in activity (politicization, the struggle for power, treasury) [21].

- Philosophers have thought a lot about the problem of the proper education of society, the basis of which should be whole knowledge (the union of the mind, emotions, spirit, will, conscience) and the "believing mind". The Slavophiles called the main condition for success in educational activities: compliance with traditions and the way of life of the nation and Orthodox values [22]

In modern Russian public thought, the Slavophilic ideas voiced above are actively developed and comprehended. The main issues being developed by the professional community of scientists are: the idea of collegiality and its interpretation (L. Shaposhnikov, A. Korolkov, S. Khoruzhiy, V. Aksyuchits, A. Ermichev, V. Bychkov [23]), issues of the connection of faith with cognitive and educational activities (A. Osipov, V. Ganichev, who writes a lot about the importance of combining faith, reason, feelings and the will of the individual), the problem of finding and developing a form of interaction between the economic realities of capitalism and the Orthodox organization of society (V. Katasonov, M. Delyagin, I. Ashmanov) and others [24].

The ideas of the Slavophiles about the special role and connection of the Orthodox faith with the Russian people, about the conditionality of culture, society and life of Russia, as well as a number of personal qualities of Russians are the most popular and broadcast in the modern public rhetoric among representatives of various professional communities (writers, journalists, actors, economists, political figures). This view is shared by: V. Averyanov, N. Rumyantseva, A. Kaplin, A. Vasiliev, V. Gusakova, V. Rasputin, V. Ganichev, V. Soloviev, V. Khotinenko, A. Soshenko, V. Kostomarov, I Glazunov, D. Babich. There are widespread ideas about the advantage and difference of Orthodoxy from other forms of the Christian faith: V. Bortko, A. Lapin, V. Voropaev, Yu. Vorobevsky, S. Khudiev, T. Mironova, E. Nikiforov. 
Statistical studies of the last decade indicate the preservation of the number of people who consider themselves Orthodox and an increase in the number of respondents who call themselves religious [25].

The problem of the Russian Orthodox Church's transformation into a state institution and its involvement in power is widely debated in society (A. Bitov, A. Lapin) [26]. There is dynamics in supporting the idea of cultivating a church with power structures and the idea that the Russian Orthodox Church should deal with the spiritual and moral state of Russian society.

The idea of the special mission of the Russian people as the spiritual saviour of mankind is in demand to a certain extent,. These Slavophile ideas are shared: V. Trostnikov, V. Filimonov, V. Krupin, A. Golovanevsky, N. Starikov, S. Baburin.

The Slavophile ideas of the community as the visible form of the embodiment of religious principles in worldly life and collegiality are of the least interest and popularity (A. Lapin).

Views like Slavophile can also be seen among official representatives of the modern Russian Orthodox Church, for example, Patriarch of Moscow and All Russia Kirill, Metropolitan of Leningrad and Ladoga John (Snychev), Protodeacon V. Vasilik, etc [27].

\section{CONCLUSION}

The philosophical heritage of the Slavophiles has on many occasions attracted social philosophical thought with the originality of the ideas put forward by them. The need to determine an independent development path and special tasks that grow out of the history and culture of the people were first recognized in the intellectual work of the Slavophiles. The priority of posing a number of socio-philosophical, and closely related religious, moral, cultural problems, issues of enlightenment and upbringing makes it possible for researchers to talk about the enormous contribution of these thinkers to the development of Russian thought and culture, and also bring us to the painful points of modern Russian society.

The above material allows us to conclude that there is a Slavophile intellectual heritage in Russian society in a significant volume, demanded at different poles and steps of the social hierarchy, both among a wide part of the population, people who are not deeply interested in philosophical problems, and among representatives of the Russian scientific community, politicians, public figures, economists, journalists, cultural and creative elite, who in their speeches call themselves supporters of the Slavophilepochvennicheskih ideas and in his books, publications, interviews, broadcast and protect them looks close.
Thus, today in Russian society it seems possible to ascertain the composition of the clearly expressed Slavophil tendency, which, in our opinion, through understanding ourselves, its foundations and roots, can become a solid base for developing a line for the country's future strategy. This idea allows us to find the main points of application of the Slavophil heritage in modern reality and determine the vector of development of social thought in Russia.

At the same time, it is necessary to add that the actualization of the Slavophile developments in no way can and should not exclude the use of the ideological heritage of other philosophical movements. On the contrary, this involves updating the traditional dispute between the Slavophiles and Westerners and its transition into a constructive and productive dialogue between representatives of various poles of modern Russian society.

\section{References}

[1] The social philosophy of Russian conservatism: a training manual / A.I. Yesyukov, N.V. Chestneyshin, D.A. Chest. Arkhangelsk: Pomeranian University, 2009. - p. 111

[2] S.A. Levitsky Essays on the history of Russian philosophy // The tragedy of freedom: selected works. - M.: Astrel, 2008.- p 653

[3] A.S. Zapesotsky What capitalism is built in Russia // National interests. 2012. No. 1 (77). [Electronic resource]. URL: http://www.ni-journal.ru/archive/7a9445dd/n12012/a13e47d5/c58b5450/ (accessed: 01.03.2020).

[4] See: A.S. Khomyakov Semiramis // Works in 2 volumes. T.1. M.: Medium, 1994. - pp. 22, 103, 353

[5] Yu.F. Samarin About the views of the Contemporary, historical and literary // Sobr. Op. in 12 volumes. T. 1. - M.: Type. A.I Mamontova and K., 1877. - p. 108

[6] I.S. Aksakov Doctrine and organic life // I.S. Aksakov Our banner is the Russian nationality. - M.: Institute of Russian Civilization, 2008. - p. 109; K.S. Aksakov On the basic principles of Russian history. Continuation // K.S. Aksakov State and people. - M.: Institute of Russian Civilization, 2009. p. 306

[7] Yu.F. Samarin Regarding the rumors about the constitution // Russian socio-political thought. 1850-1860s: Reader. - M. Publishing house of Moscow University, 2012. - p. 255

[8] Program principles of the Russian Monarchist Movement [Electronic resource]. URL: http://www.monarhia.ru/?id=10\&show = program (accessed: 12/07/2019).

[9] See: N.S. Mikhalkov Law and Truth. Manifesto of Enlightened Conservatism. - M.: Eksmo, 2017. - 96 p. [Electronic resource] URL: http: //www.danilidi.ru/books / publicistika / ManifestoEnlightened-conservatism_Nikita-Mikhalkov.html (accessed 01/25/2019); M.B. Smolin Church, State and Revolution: Sat articles. - M.: RISI, 2013. - 94 p.; V. Karpets Monarchis socialism. [Electronic resource]. URL: https://karpets.livejournal.com/248896.html (accessed date: 03/11/2019)

[10] See: N.A. Narochnitskaya Russian development code. - M.: Book World, 2012. - 352 p.; A.A. Prokhanov, V.V. Averyanov, A. Dugin et al. Doctrine of the Russian World. - M.: Book World, 2016 .- $641 \mathrm{p}$ 
[11] R.V. Mikhailov Russian-French dialogue On the crisis of European civilization // Policy. Political research. - M.: "Editorial Board of the journal "Polis"("Political Studies"), 2017. No. 3. - pp.179-191; Reforming the system of organization of local government in large cities and metropolitan areas: possible approaches. Analytical note / comp. D. Badovsky, A. Pozhalov, V. Vinogradov. - M.: ISEPI Fund, 2013.- 22 p.

[12] I.S. Aksakov What does it mean to leave our government on a historic popular path? // I.S. Aksakov Our banner is the Russian nationality. - M.: Institute of Russian Civilization, 2008, - p. 222

[13] See: K.S. Aksakov Note K.S. Aksakova "On the Internal State of Russia", presented to the Emperor Emperor Alexander II in 1855 // Russian Socio-Political Thought. 1850-1860s: Reader. M.: Publishing house of Moscow University, 2012. - pp. 54-56

[14] I.V. Kireevsky The spiritual foundations of Russian life. - M.: Institute of Russian Civilization, 2007. - p. 354; K.S. Aksakov Editorials of the Molva newspaper // K.S. Aksakov State and people. - M.: Institute of Russian Civilization, 2009. - p. 195

[15] See: What Russians dream of. Analytical report of the Institute of Sociology of the Russian Academy of Sciences. - M.: IS RAS, 2012 .- pp. 18-19, 25-28

[16] See: A.S. Panarin Orthodox civilization. - M.: Institute of Russian Civilization, 2014. - 1248 p.; A.A. Korolkov Spiritual anthropology. [Electronic resource]. URL: http://www.xpaspb.ru/libr/Korolkov/1-duhovnaya-antropologiya.html\#_1-7 (accessed: 01/06/2019); Yu.M. Polyakov The desire to be Russian // Literary newspaper. - M. 2018. No. 15. [Electronic resource]. URL: http://www.lgz.ru/article/-15-6639-11-042018/zhelanie-byt-russkim/ (accessed: 11/06/2019).

[17] A.I. Solzhenitsyn Russia in a cliff. - M.: Russian Way, 2006. 208 p.; 2013: Red threads of Vladimir Putin (report by V. Putin, read on 09/19/2013 at the Valdai club) // Russian newspaper. 2013. No. 216 (6192). - pp. 2-3

[18] A.V. Schipkov Social Tradition: Monograph. - M.: AST-PRESS BOOK, 2017.- 320 p.

[19] A.S. Khomyakov Semiramis // Works in 2 volumes. T.1. - M.: Medium, 1994 .- p. 148

[20] A.S. Khomyakov The Church is One // Works in 2 volumes. T.2. - M.: Medium, 1994. - p. 7; I.V. Kireevsky A note on the attitude of the Russian people to tsarist authority // Spiritual Foundations of Russian Life. - M.: Institute of Russian Civilization, 2007. - p. 44

[21] Russian philosophy: encyclopedia / Ed. M.A. Olive. Comp. P.P. Apryshko, A.P. Poles. - M.: Algorithm, 2007 .- p. 546

[22] I.V. Kireyevsky Excerpts // Spiritual foundations of Russian life. - M.: Institute of Russian Civilization, 2007. - pp.310-312

[23] L.E. Shaposhnikov A. S. Khomyakov: man and thinker: monograph. - N. Novgorod: Publishing House of the NGPU and the Nizhny Novgorod Humanitarian Center, 2004. - 180 p.; V.V. Aksyuchits Russian character. The nature of morality. [Electronic resource]. URL: http://www.pravoslavie.ru/1072.html (accessed: 11/06/2019)

[24] A.I. Osipov What spirituality do we live? // Image. - 1996. No. 2 (6). [Electronic resource]. URL: http: //radonezh.ru/analytics/kakoy-dukhovnostyu-my-zhivem-

54660.html (accessed date: 01/09/2020); V. Ganichev Russian literature and the Writers' Union. To the reconstruction of the Society of Russian Literature. Speech at the Plenum of the Union of Writers of Russia in 2016 [Electronic resource]. URL: http://ruskline.ru/analitika/2016/04/06/russkaya_slovesnost_i_so yuz_pisatelej/ (accessed: 01/06/2019); V.Yu. Katasonov, V.N. Trostnikov, G.M. Shimanov History as Providence of God. - M .: Institute of Russian Civilization, Publishing House "Oxygen", 2016. - 640 p.

[25] E.Kochergina Press release "Religiosity" from 07/18/2017 // Levada Center. [Electronic resource]. URL: https: //www.levada.ru / 2017/07/18 / religioznost / (accessed 01/06/2019)

[26] A. Lapin Russian faith. [Electronic resource]. URL: http://derzava.com/aleksandr-lapin-russkaya-vera.html (accessed date: 1/6/2019); S. Grachev Being out of the crowd. Interview with A. Bitov // Arguments and Facts. - M.: AMF, 2016. No. 51. - p. 3

[27] Cyril, Patriarch of Moscow and All Russia. Seven words about the Russian world / comp. A.V. Schipkov. - M.: World Russian People's Cathedral, 2015. - 120 p.; Mit. John (Snychev) Overcoming the Troubles (Word to the Russian people). - SPb. Tsarskoe deed, 1995. - 352 p.; V. Vasilik The ideology of Ukrainian statehood is built on a spiritually rotten basis [Electronic resource]. URL https://radonezh.ru/monitoring/ideologiya-ukrainskoygosudarstvennosti-postroena-na-dukhovno-gniloy-osnovediakon-vladimir-vasilik-94811.html (accessed: 01/06/2019). 